\title{
POMOC SPOŁECZNA \\ WOBEC ZJAWISKA WYKLUCZENIA SPOŁECZNEGO OSÓB Z CHOROBAMI PSYCHICZNYMI
}

\begin{abstract}
Streszczenie: Artykuł dotyczy problemu wykluczenia społecznego osób z chorobami psychicznymi oraz wybranych zadań $\mathbf{z}$ obszaru pomocy społecznej podejmowanych na rzecz przeciwdziałania temu zjawisku. Osoby $\mathbf{z}$ chorobami psychicznymi doświadczają wielu problemów w codziennym funkcjonowaniu w podstawowych obszarach życia społecznego, dlatego należą do głównych grup zagrożonych wykluczeniem społecznym. Zadania na rzecz integracji podejmowane są przez system pomocy społecznej. W artykule zasygnalizowane zostały niektóre formy oparcia społecznego realizowane zwłaszcza $\mathbf{w}$ obszarze pracy socjalnej.
\end{abstract}

Słowa kluczowe: pomoc społeczna, wykluczenie społeczne, osoby $\mathbf{z}$ chorobami psychicznymi, praca socjalna

\section{Wprowadzenie}

Zdrowie i dobre samopoczucie psychiczne to główne elementy jakości życia pojedynczych osób, rodzin i całego społeczeństwa. Przemiany społeczno-gospodarcze ostatnich lat negatywnie odbiły się na kondycji psychicznej ludności. Problemy dotyczące zdrowia psychicznego są powszechne, coraz więcej osób cierpi na różnego rodzaju zaburzenia w tej sferze, chociażby depresję, która jest nazywana dżumą XXI wieku. Szacuje się, że „co czwarta osoba w Europie doświadcza ich co najmniej raz w życiu, a wiele kolejnych osób odczuwa je pośrednio" (Rezolucja Parlamentu Europejskiego z dnia 19 lutego $2009 \mathrm{r}$. w sprawie zdrowia psychicznego, s. 1). Występowanie chorób psychicznych jest potęgowane przez nierówności społeczne i gospodarcze - wskaźniki stanu zdrowia psychicznego są gorsze w grupach słabiej uprzywilejowanych i spychanych na margines, np. wśród bezrobotnych, niepełnosprawnych, przewlekle chorych, uzależnionych. Dyskryminacja i wykluczenie społeczne, których doświadczają osoby z chorobami psychicznymi oraz ich rodziny, to nie tylko konsekwencja zaburzeń zdrowia, ale również stygmatyzacji, odrzucenia przez społeczeństwo. Zaburzenia psychiczne powodują izolację społeczną, natomiast chory potrzebuje spotkania $\mathrm{z}$ drugim człowiekiem i uczestniczenia w życiu wspólnoty rodzinnej i lokalnej. 


\section{Zjawisko wykluczenia społecznego}

Pojęcie „wykluczenie społeczne” zaczęło być stosowane z większym natężeniem w pierwszych latach XXI wieku m.in. w związku z decyzją o przystąpieniu Polski do Procesu Inkluzji Społecznej. Przedstawiciele Komisji Europejskiej i polskiego Rządu w grudniu 2003 r. podpisali Wspólne Memorandum na Rzecz Integracji Społecznej, w którym określono wyzwania dla polskiej polityki społecznej dotyczące również problemu wykluczenia określonych grup społecznych (Szarfenberg 2007, s. 18).

W literaturze przedmiotu oraz w licznych dokumentach krajowych i międzynarodowych definicje wykluczenia społecznego koncentrują się albo na określonych wymiarach zjawiska, np. ograniczeniach instytucjonalno-prawnych, albo na dominującym ryzyku (zagrożeniu wykluczeniem), np. ubóstwie czy braku kwalifikacji, albo na grupach osób dotkniętych już wykluczeniem społecznym (np. bezdomnych, uzależnionych), albo na ukazywaniu obszarów, do których nastąpiło ograniczenie dostępu (np. do konsumpcji, informacji, kultury). Formułowane są też definicje opisujące proces wykluczania społecznego poprzez ukazywanie jego głównych przyczyn. Wykluczenie społeczne - najprościej ujmując - polega na niepodejmowaniu zwyczajowej i społecznie akceptowanej drogi życiowej lub wypadaniu z niej; dotyczy osób, rodzin lub grup ludności (Narodowa Strategia Integracji Społecznej dla Polski ${ }^{1}$, s. 21):

- żyjących w niekorzystnych warunkach ekonomicznych (ubóstwo materialne),

- dotkniętych niekorzystnymi procesami społecznymi, wynikającymi z masowych i dynamicznych zmian rozwojowych, np. dezindustrializacji, kryzysów, gwałtownego upadku branż czy regionów; nie wyposażonych w kapitał życiowy umożliwiający im normalną pozycję społeczną,

- nieposiadających odpowiedniego poziomu kwalifikacji, mających problemy z wejściem na rynek pracy lub założeniem rodziny, co dodatkowo utrudnia dostosowywanie się do zmieniających się warunków społecznych i ekonomicznych,

- nieposiadających dostępu do odpowiednich instytucji pozwalających na wyposażenie w kapitał życiowy, jego rozwój i pomnażanie, co ma miejsce w wyniku niedorozwoju tych instytucji spowodowanego brakiem priorytetów, brakiem środków publicznych, niską efektywnością funkcjonowania,

- doświadczających przejawów dyskryminacji, zarówno wskutek niedorozwoju właściwego ustawodawstwa, jak i kulturowych uprzedzeń oraz stereotypów,

- posiadających cechy utrudniające im korzystanie z powszechnych zasobów społecznych ze względu na zaistnienie: niesprawności, uzależnienia, długotrwałej choroby albo innych cech indywidualnych,

- będących przedmiotem niszczącego działania innych osób, np. przemocy, szantażu, indoktrynacji.

Zatem wykluczenie społeczne to zjawisko stanowiące przeciwieństwo społecznej integracji, gdyż powoduje, że niektóre jednostki i grupy nie mogą uczestniczyć w życiu społecznym lub nie są uznawane za pełnych i równych członków społeczeństwa. W analizie

1 Dokument przygotowany przez Zespół Zadaniowy do Spraw Reintegracji Społecznej, któremu przewodniczył Minister Gospodarki, Pracy i Polityki Społecznej - Jerzy Hausner. Zespół został powołany 14.04.2003 r. przez Prezesa Rady Ministrów. 
tego zjawiska mamy do czynienia z kilkoma nakładającymi się wymiarami marginalizacji, ponieważ obejmować może ono niski poziom dobrobytu, brak zdolności do skutecznego uczestnictwa w życiu społecznym poprzez pracę, brak dostępu do uprawnień społecznych i politycznych oraz do instrumentów zabezpieczenia społecznego. Wykluczenie społeczne obejmuje również niedostatek praw socjalnych, niemożność dokonywania wyborów dotyczących własnego życia i korzystania z przysługujących uprawnień obywatelskich, ekonomicznych, cywilnych i politycznych (Kowalczyk 2012, s. 111).

Osoby pozostające na peryferiach społeczeństwa mają utrudnione pełne uczestnictwo w życiu społecznym z powodu ubóstwa, braku podstawowych kompetencji i możliwości zdobywania kwalifikacji lub z powodu dyskryminacji. Proces ten oddala ludzi od możliwości znalezienia pracy, uzyskania dochodu i wykształcenia, jak również od aktywności społecznej. Osoby takie mają ograniczony dostęp do władzy i do ciał decyzyjnych, czują się bezsilne i niezdolne wpływać na decyzje dotyczące ich codziennego życia (SzaturJaworska 2010, s. 235).

Jak już zostało przedstawione wcześniej, osoby wykluczone to ludzie (grupy), którzy nie mają możliwości pełnego udziału w życiu społecznym, nie mogą korzystać z formalnie przypisanych im praw oraz doświadczają innego typu barier. Zaliczają się do nich przede wszystkim dzieci i młodzież ze środowisk zaniedbanych lub wychowujące się poza rodziną, osoby starsze, niepełnosprawne, grupy społeczne, np. mniejszości etniczne, osoby długotrwale bezrobotne, bezdomnych, byłych więźniów, osoby uzależnione, z chorobami psychicznymi, dotknięte ubóstwem, osoby z niskim poziomem wykształcenia i kwalifikacji.

W odniesieniu do osób z chorobami psychicznymi wykluczenie społeczne obejmuje przede wszystkim negatywne postawy dostrzegane w społeczeństwie, a zwłaszcza dystansowanie się i unikanie wchodzenia w nieformalne kontakty, upowszechnianie negatywnych, uproszczonych, stereotypowych opinii, wprowadzenie ograniczeń możliwości działania w określonym obszarze (delegitymację), blokowanie dostępu do pewnych form aktywności "zarezerwowanych" dla osób zdrowych (Jackowska 2009, s. 656). Dostrzega się również powszechną stereotypizację, stygmatyzację, a czasami wręcz lęk przed chorobą psychiczną, co sprawia, że osoby dotknięte zaburzeniami psychicznymi mają szczególne trudności w realizacji ról społecznych, a tym samym należą do kategorii szczególnie zagrożonych wykluczeniem społecznym (Mesjasz, Goleński 2012, s. 13).

\section{Istota i wybrane objawy chorób psychicznych}

Choroby psychiczne są stanem, w którym dochodzi do zatarcia wyraźnej granicy między światem realnym a światem urojeń i halucynacji, na przykład podczas występowania zaburzeń psychotycznych, zaburzeń urojeniowych, schizofrenii, depresji, nerwicy czy psychotycznych zaburzeń afektywnych. Człowiek doświadcza wówczas rozbicia granic własnego „ja”, czemu towarzyszą poważne zaburzenia emocjonalne.

Występuje wiele rodzajów chorób psychicznych, które różnią się między sobą w zakresie etiologii, objawów, przebiegu, sposobów leczenia itd. W Polsce obowiązuje Międzynarodowa Statystyczna Klasyfikacja Chorób i Problemów Zdrowotnych - system ICD-10 (http://www. csioz.gov.pl/src/files/klasyfikacje/ICD1oTomI.pdf), wyodrębniająca zasadnicze grupy diagnostyczne i ich kody:

1) organiczne zaburzenia psychiczne włącznie z zespołami objawowymi - Foo-Fog; 
2) zaburzenia psychiczne i zaburzenia zachowania spowodowane używaniem substancji psychoaktywnych - F10-F19;

3) schizofrenia, zaburzenia typu schizofrenii (schizotypowe) i urojeniowe - F2o-F29;

4) zaburzenia nastroju (afektywne) - $\mathrm{F}_{3} 0-\mathrm{F}_{39}$;

5) zaburzenia nerwicowe, związane ze stresem i pod postacią somatyczną - F40-F49;

6) zespoły behawioralne związane z zaburzeniami fizjologicznymi i czynnikami fizycznymi - F50-F59;

7) zaburzenia osobowości i zachowania dorosłych - F6o-F69;

8) upośledzenie umysłowe - F70-F79;

9) zaburzenia rozwoju psychicznego (psychologicznego) - F8o-F89;

10) zaburzenia zachowania i emocji rozpoczynające się w dzieciństwie i w wieku młodzieńczym - F9o-F98;

11) nieokreślone zaburzenia psychiczne - F99.

Uaktywnienie się objawów psychiatrycznych powoduje duży stres, niepokój, brak umiejętności radzenia sobie z nową sytuacją. W większości przypadków symptomy choroby rozwijają się stopniowo. Często poprzedzone są tzw. fazą prodromalną charakteryzującą się zaburzeniami funkcjonowania, takimi jak izolowanie się od innych ludzi, zaniedbywanie zasad higieny, niekontrolowane wybuchy gniewu. Ostatecznie objawy wchodzą w fazę aktywną, w której występują z pełną mocą. Prowadzi to często do bierności, izolowania się, zniechęcenia, chęci ucieczki bądź wrogości i agresji (Regulska 2010, s. 179). Do podstawowych objawów zaburzeń psychicznych typu schizofrenii należą (Seligmann, Walker, Rosenhan 2003, s. 448-450):

- echo myśli, nasyłanie czy odciąganie myśli lub rozgłaśnianie myśli;

- urojenia oddziaływania, wpływu, owładnięcia, spostrzeżenia urojeniowe;

- głosy komentujące czy dyskutujące bądź wychodzące z wnętrza ciała;

- utrwalone omamy wszelkiej modalności, utrwalone myśli nadwartościowe;

- neologizmy, przerwy czy wstawki w toku myślenia, prowadzące do rozkojarzenia wypowiedzi;

- zachowanie katatoniczne, takie jak pobudzenie, zastyganie czy gibkość woskowata, negatywizm, mutyzm i stupor;

- objawy negatywne, takie jak apatia, zubożenie wypowiedzi i niedostosowane reakcje emocjonalne.

Należy podkreślić, iż choroba psychiczna nie oznacza dysfunkcji intelektualnych, jakie występują u osób z niepełnosprawnością intelektualną. Jednakże niektóre symptomy chorobowe czy skutki uboczne przyjmowanych leków, mogą powodować występowanie zaburzeń procesów myślowych i sfery emocjonalnej oraz pojawiające się na tym tle patologiczne zachowania.

Choroba psychiczna stanowi jedną z przyczyn niepełnosprawności - około 80\% chorujących psychicznie to osoby długotrwale niepełnosprawne, a spośród tej grupy ponad 90\% to osoby długotrwale lub trwale pozbawione możliwości zatrudnienia (Kaszyński 2006, s.6). Niepełnosprawność spowodowana chorobą psychiczną ogranicza zdolność adekwatnego pełnienia ról społecznych, przede wszystkim w zakresie rozumienia oraz postrzegania wymagań i oczekiwań związanych z tymi rolami. Stan taki ma miejsce w przypadku zaburzeń psychicznych, przy których mechanizmy umysłowe i objawy wiążą się z poważnym ograniczeniem kompetencji psychofizycznych, intelektualnych, emocjonalnych i społecznych, 
przebieg jest intensywny, objawy występują przewlekle lub nawracają, a dodatkowo mają szeroki zakres w rożnych sferach funkcjonowania, w tym również funkcjonowania na rynku pracy (Trzebińska 2006, s. 53).

Przebieg większości chorób psychicznych ujemnie wpływa na funkcjonowanie rodzinne i społeczne osób doświadczających takich problemów zdrowotnych. W społeczeństwie występują liczne uprzedzenia wobec tej grupy chorych, którym przypisuje się negatywny wizerunek, a nierzadko obarcza odpowiedzialnością za doprowadzenie się do takiego stanu. Osoby z zaburzeniami psychicznymi często są spychane na margines życia społecznego z powodu braku wystarczających warunków umożliwiających im zaspokajanie podstawowych potrzeb życiowych, zapewnienie godnych warunków życia, integracji społecznej oraz z powodu funkcjonujących barier i stereotypów.

\section{Problematyka integracji społecznej osób chorych psychicznie w zadaniach pomocy społecznej}

Ze względu na potrzebę przeciwdziałania wykluczeniu społecznemu osób z chorobami psychicznymi oraz doświadczane przez nich trudności w funkcjonowaniu w rodzinie i środowisku istotne znaczenie posiada podtrzymywanie i rozwijanie umiejętności niezbędnych do samodzielnego życia i zaspokajania podstawowych potrzeb. Chorzy i ich rodziny są członkami społeczności lokalnych - powinni pozostać we własnym środowisku, w którym należy stworzyć odpowiednie warunki dające takie same szanse dostępu do wszystkich dziedzin życia społecznego, jak w przypadku osób zdrowych. W integracji społecznej bardzo ważnym elementem jest pomoc ukierunkowana przede wszystkim na przywracanie sprawności psychicznej i aktywizacja, która polega na ciągłym stymulowaniu do podejmowania zadań i ról społecznych. Integracja osób z chorobami psychicznymi ze społecznością polega na ich wspieraniu w osiągnięciu samodzielności w codziennym życiu, promowaniu ich pracy i twórczości, pomocy w budowaniu życia rodzinnego oraz obdarzania ich szacunkiem, przyjaźnią i zaufaniem (Juros 1997, s. 21).

Ważną rolę w tym zakresie pełnią działania podejmowane w obszarze pomocy społecznej. Wsparcie świadczone osobom z chorobami psychicznymi w tym systemie udzielane jest w oparciu o przepisy Ustawy o ochronie zdrowia psychicznego z dnia 19 sierpnia $1994 \mathrm{r}$. (Dz. U. z 1994 r., nr 111, poz. 535) oraz Ustawy o pomocy społecznej z dnia 12 marca 2004 r. (Dz. U. z 2004 r., nr 175, poz. 1362 z późn. zm.). Jednostki organizacyjne pomocy społecznej $\mathrm{w}$ porozumieniu $\mathrm{z}$ zakładami psychiatrycznej opieki zdrowotnej organizują różne formy oparcia społecznego dla osób, które z powodu choroby psychicznej lub niepełnosprawności intelektualnej mają poważne trudności w życiu codziennym, zwłaszcza w kształtowaniu swoich stosunków z otoczeniem, w zakresie edukacji, zatrudnienia oraz spraw bytowych. Oparcie społeczne polega w na podtrzymywaniu i rozwijaniu umiejętności niezbędnych do samodzielnego, aktywnego życia; na organizowaniu w środowisku społecznym pomocy ze strony rodziny, innych osób, grup, organizacji społecznych i instytucji oraz na udzielaniu pomocy finansowej, rzeczowej oraz innych świadczeń systemu pomocy społecznej (art. 8 Ustawy o ochronie zdrowia psychicznego z dnia 19 sierpnia 1994 r., Dz. U. z 1994 r., $\mathrm{nr} 111$, poz. 535).

Realizacja pracy socjalnej skoncentrowana jest na usamodzielnieniu osoby z zaburzeniami psychicznymi oraz odbudowaniu lub polepszeniu jej funkcjonowania w lokalnej 
społeczności. Dotyczy to funkcjonowania w rodzinie, w różnorodnych warunkach społecznych i w innych dziedzinach składających się na całokształt ludzkiego życia. Podejmowanie pracy socjalnej ogniskuje się wokół poprawy, wzmacniania lub odzyskiwania zdolności tych osób do prawidłowego pełnienia ról społecznych. Obejmuje ona zwłaszcza rozeznanie problemów dotyczących osób chorych, motywowanie do badań diagnostycznych i systematycznego leczenia w poradniach zdrowia psychicznego oraz wspieranie osoby i rodziny. Pracownik socjalny w realizacji tych zadań współpracuje z zakładami psychiatrycznymi opieki zdrowotnej, sądami i organizacjami działającymi na rzecz osób z zaburzeniami psychicznymi.

W ramach pracy socjalnej do osoby doświadczającej choroby psychicznej może zostać skierowana pomoc o charakterze finansowym, materialnym, usługowym lub dotyczącym poradnictwa i wsparcia psychicznego. Istotna jest również pomoc w przeprowadzeniu procesu klasyfikacji niepełnosprawności wynikającej z choroby. Orzeczenie pozwala na uzyskanie prawnego statusu osoby niepełnosprawnej, który daje możliwość otrzymania różnych świadczeń, ulg i uprawnień w wielu dziedzinach (rehabilitacja, pomoc finansowa, ulgi komunikacyjne, podatkowe, szkolnictwo, kultura itd.).

Wśród działań na rzecz wsparcia osób z chorobami psychicznymi, organizowanych w obszarze pomocy społecznej, należy wymienić świadczenie specjalistycznych usług opiekuńczych w miejscu zamieszkania chorego. Usługi opiekuńcze świadczone w miejscu zamieszkania pozwalają na odejście od instytucjonalnej pomocy. Ponadto specjalistyczna opieka w domu ułatwia budowanie systemu wsparcia społecznego dla osób chorych, daje możliwość lepszego poznania ich warunków życiowych, sytuacji rodzinnej, a przez to skutecznego im pomagania.

W systemie pomocy społecznej podejmowane są działania obejmujące rehabilitację psychiczną, społeczną i zawodową osób z chorobami psychicznymi. Oddziaływania te organizowane i realizowane są w ośrodkach wsparcia, do których zaliczyć należy przede wszystkim środowiskowe domy samopomocy, kluby integracji oraz warsztaty terapii zajęciowej przygotowujące do podjęcia pracy w warunkach chronionych.

Chorzy wymagający całodobowej opieki, którzy są niezdolni do samodzielnego funkcjonowania w codziennym życiu, doświadczający samotności lub braku dostatecznej opieki ze strony rodziny, mogą zostać objęci całodobową i długotrwałą opieką w domach pomocy społecznej dla osób przewlekle psychicznie chorych.

Pomoc osobom z zaburzeniami psychicznymi wymaga współpracy interdyscyplinarnej, przy czym wsparcie środowiskowe jest istotne tak, jak działania sensu stricto medyczne, gdyż umożliwiają chorym funkcjonowanie i pełnienie ról w rodzinie i społeczeństwie.

\section{Podsumowanie}

Sytuacja osób z zaburzeniami psychicznymi jest trudna i złożona. Działania mające na celu zapobieganie wykluczeniu społecznemu tych osób mogą być realizowane przez przedstawione $\mathrm{w}$ niniejszym artykule formy wsparcia z systemu pomocy społecznej, ale również poprzez realizację w środowisku lokalnym programów integracyjnych czy kampanii edukacyjno-informacyjnych. Efektywne wsparcie dla tej kategorii osób wymaga zintegrowania systemu wsparcia $\mathrm{z}$ uwzględnieniem nie tylko sieci medycznej opieki psychiatrycznej, lecz również oparcia społecznego realizowanego głównie w obszarze pomocy 
społecznej. Istotną kwestią jest nie tylko rozwój opieki środowiskowej obejmującej pomoc psychiatryczną i wsparcie dla osób chorujących psychicznie, ale również objęcie pomocą ich rodzin, bowiem osoby najbliższe stanowią podstawową siłę w opiece nad chorym.

Eliminowanie, zmniejszanie lub kompensowanie wszelkich barier należy do zadań odpowiednich instytucji i całego społeczeństwa, aby każdej osobie umożliwić korzystanie z dóbr publicznych, jednocześnie respektując jej prawa i przywileje. Miejsce osób z chorobami psychicznymi w społeczeństwie nie zależy tylko od organizacji systemu instytucji, od jakości prawa i zakresu jego stosowania w praktyce. Zależy również od tego, czy da się przełamać obojętność, bierność, egoizm, niezrozumienie w postawach i zachowaniach konkretnych ludzi, grup i całej społeczności.

\section{Bibliografia}

Jackowska E. (2009). Stygmatyzacja i wykluczenie społeczne osób chorujących na schizofrenię - przegląd badań i mechanizmy psychologiczne. „Psychiatria Polska”, t. XLIII, nr 6.

Juros A. (1997). Rola i sposoby animowania grup samopomocowych jako warunek integracji osób niepełnosprawnych w społeczności lokalnej. W: Juros A., Otrębski W. (red.). Integracja osób z niepetnosprawnościa w społeczności lokalnej. Lublin: FŚCEDS.

Kaszyński H. (2006). Osoby chore psychicznie jako grupa beneficjentów organizacji pozarządowych świadczacych ustugi na rynku pracy. Warszawa: FISE.

Kowalczyk O. (2012). Rola pomocy osobistej w realizacji praw społecznych osób chorych psychicznie. W: Gawor A., Borecki Ł. (red.). Strategie promocji zatrudnienia osób z zaburzeniami psychicznymi. Opole: Top Media House.

Mesjasz K., Goleński W. (2012). Instytucjonalne formy integracji społeczno-zawodowej osób z zaburzeniami psychicznymi w województwie opolskim. W: Gawor A., Borecki Ł. (red.). Strategie promocji zatrudnienia osób z zaburzeniami psychicznymi. Opole: Top Media House.

Narodowa Strategia Integracji Społecznej dla Polski.

Regulska A. (2010). Osoba niepetnosprawna chora psychicznie w rodzinie. W: Regulska A. (red.). Pedagogika rodziny - wybrane problemy. Warszawa: Bonus Liber.

Rezolucja Parlamentu Europejskiego z dnia 19 lutego 2009 r.w sprawie zdrowia psychicznego, W: Dzienniki Unii Europejskiej, seria C(E), nr 76, poz. 5 z dn. 25. 03. 2010 r.

Szarfenberg R. (2007). Ubóstwo, marginalność i wykluczenie społeczne. W: Firlit-Fesnak G., Szylko-Skoczny M. (red.). Polityka społeczna. Warszawa: Państwowe Wydawnictwo Naukowe.

Szatur-Jaworska B. (2010). Ubóstwo i wykluczenie społeczne seniorów. W: Szarfenberg R., Żołędowski C., Theiss M. (red.). Ubóstwo i wykluczenie społeczne. Perspektywa poznawcza. Warszawa: Dom Wydawniczy Elipsa.

Seligmann M. E. P., Walker E. F., Rosenhan D. L. (2003). Psychopatologia. Poznań: Wydawnictwo Zysk i S-ka.

Trzebińska E. (2006). Przeszkody i szanse aktywizacji zawodowej osób niepetnosprawnych na tle chorób psychicznych, Psychologiczna analiza problemu. Projekt badawczy nr WUE/o041/IV/o5 pt.: „Psychospołeczne uwarunkowania aktywności zawodowej osób niepetnosprawnych". Warszawa: Szkoła Wyższa Psychologii Społecznej i Instytut Psychologii PAN. 
Ustawa z dnia 12 marca 2004 r. o pomocy społecznej, Dz. U. z 2004 r., nr 175, poz. 1362 z późn. zm.

Ustawa z dnia 19 sierpnia 1994 r. o ochronie zdrowia psychicznego, Dz. U., nr 111, poz. 535.

\title{
WELFARE IN THE FACE OF SOCIAL EXCLUSION OF MENTALLY ILL PERSONS
}

\begin{abstract}
The article is regarding the problem of social exclusion of mentally ill persons and of chosen assignments on the area of the welfare taken for the counteraction for this phenomenon. Everyday mentally ill persons experience many problems in basic areas of the social life, therefore they belong to the major groups threatened with the social exclusion. Tasks for integration are being undertaken by the system of the welfare. In the article some forms of the social support carried out especially in the area of the social work were indicated.
\end{abstract}

Key words: welfare, social exclusion, mentally ill person, social work

Agnieszka Regulska - doktor nauk humanistycznych w zakresie pedagogiki, studia podyplomowe w zakresie organizacji pomocy społecznej; adiunkt na Uniwersytecie Kardynała Stefana Wyszyńskiego w Warszawie. Podejmuje badania z zakresu pedagogiki rodziny, pedagogiki opiekuńczej, pracy socjalnej i filozofii wychowania. Adres e-mail: a.regulska@uksw.edu.pl 